\title{
SZEMLE
}

Educatio 28 (4), pp. 838-840 (2019)

DOI: $10.1556 / 2063.28 .2019 .4 .14$

\section{Alternatív lehetőségek AZ AMERIKAI FELSŐOKTATÁSBAN}

\author{
RÉKASI NIKOLETT
}

ELTE Neveléstudományi Doktori Iskola

\begin{abstract}
Barbara Schneider (ed.) Handbook of the Sociology of Education in the 21st Century. (Handbooks of Sociology and Social Rresearch.) Cham (Switzerland), 2018. Springer International Publishing, xxxvii + 597 p. ISBN 978-3-319-76694-2 (eBook)
\end{abstract}

A 2018-ban megjelent kötet a bevezetö szerint egyfajta szociológiai áttekintés, amely azokat az oktatási problémákat kívánja feltárni és bemutatni, amelyekkel a mai amerikai egyesült államokbeli oktatásnak szembe kell néznie. A kiadvány szerzői öt részben és 25 fejezetben mutatják be az egyes témákban releváns elméleteket, megközelítéseket, ha szükséges, időnként kissé módosítva is őket, új utakat keresve a modern gondolatoknak. Föleg szociológusoknak íródott, de pedagógusként is érdekes, érdemes elolvasni, hiszen minden rész arra a kérdésre (is) keresi a választ, hogy milyen tényezők játszanak szerepet abban, hogy egy tanuló sikeres vagy éppen sikertelen lesz az oktatás során. Erre a kérdésre pedig itt Európában, Magyarországon is, minduntalan keressük a választ. A tengerentúli gyakorlatok megismerése tehát számunkra is tanulságos lehet.

Jelen írás a könyv negyedik részét (Educational Opportunities and the Transition into Adulthood) mutatja be, ez illeszkedik leginkább az Educatio mostani lapszámának tematikájához. A rész öt fejezetből áll, amelyek mindegyike a felsőoktatásban való részvételről, a hallgatók tapasztalatairól, illetve a különböző alternatív lehetőségekről szól.

A könyv számozása szerinti 16 . fejezetben (ez a szóban forgó 4. rész 1. fejezete) Michal Kurlaneder és Jacob Hibel az egyetemi, föiskolai hallgatók által bejárt különféle tanulási utakról ír, illetve arról, hogy választásaik, döntéseik során mik voltak a motiváló vagy hátráltató tényezők. Az írás elsősorban szakirodalmi áttekintés, amelynek során a szerzők öszszefoglalják azt, hogy hogyan jellemezhetők a hallgatók oktatásban bejárt ösvényei egészen a kora gyermekkortól a felnőtt évekig. Az áttekintés több szempont mentén halad: vizsgálják az egyének döntéseit, a curriculumot (vagyis a tantervet), az információs akadályokat és lehetőségeket is. Az írás a College for All elv égisze alatt elemzi a már rendelkezésre álló szakirodalmi adatokat, és megállapítja, hogy bár mindenféle szociális háttérrel rendelkező hallgatók is tapasztalnak növekedést az oktatás területén, a strukturális problémák, mint például a rasszból vagy a hátrányos szociális helyzetből adódó lemaradások, még mindig léteznek, és szá- 
mottevő tényezőt alkotnak az amerikai oktatás színterén.

A 17. fejezet (Student Experiences in College) teljes egészében az egyetemi hallgatókra koncentrál. Az előzőhöz hasonlóan ez is részletes szakirodalmi áttekintés, amelynek fókusza a "megtapasztalt egyetemi lét”. (Ebben az esetben a klasszikus négyéves alapképzésre kell gondolni.) A szerzők különböző aspektusokból elemezték a témában rendelkezésre álló angol nyelvű szakirodalmat, mint például gender, etnikai hovatartozás, illetve szexuális orientáció, és megállapítják, hogy az amerikai felsőoktatási rendszer ma is küzd azzal, hogy a különböző hátrányos helyzetủ csoportok számára esélyegyenlőséget teremtsen.

A 18. fejezetben (The Community College Experience and Educational Equality: Theory, Research and Policy) Lauren Schudde és Eric Grodsky egy Magyarországon kevéssé ismert oktatási intézményről, a community college-ról (szabad fordításban: a közösségi főiskoláról) ír. $\mathrm{A} z$ elözőekhez hasonlóan részben ez a fejezet is részletes szakirodalmi áttekintés és elemzés. A szerzők összefoglalják a community college történelmét, kitérve a szociológiai szempontból fontos elméletekre, és bemutatják a terület kutatásának kulcskérdéseit. Megtudhatjuk, hogy ezek a kétéves felsőfokú képzést nyújtó intézmények, amelyek az Egyesült Államokban a 20. század elején jelentek meg, ma is jelentős szerepet töltenek be az ország felsőoktatási rendszerében, hiszen remek alternativát kinálnak a szegényebb, hátrányos szociális helyzetben élők számára a továbbtanulásra. A releváns szociológiai modellek megtárgyalása mellett a fejezet elöremutató is, hisz igyekszik támpontokat adni a jövő kutatásainak olyan tekintetben, hogy melyek azok a területek, amelyek további érdekes vizsgálódások táptalajai lehetnek a community college fejlesztését, még sokrétűbb kihasználását illetően.

A könyv következő fejezete (College for All: Alternative Options and Procedures) azt vitatja meg, hogy a státuselérés (status attainment) hogyan hozható összefüggésbe az iskolai teljesítménnyel, valamint az azt befolyásoló faktorokkal. A kvalitatív kutatásuk során a szerzők félig strukturált interjúkat vettek fel olyan felsőoktatásban tanuló egyénekkel, akiknek a tanulási útjuk eltér az Egyesült Államokban átlagosnak számító 4 éves, 18-22 éves kor között abszolvált egyetemi tanulmányoktól. A kutatásban idősebb, családos, teljes vagy részmunkaidőben dolgozó egyének nyilatkoztak tapasztalataikról, amelyeket a kutatók többek között úgy összegeztek, hogy a felsőoktatásban való részvétel nemcsak a tradicionális elgondolásba illő személyek sajátja már, hanem megkerülhetetlenül megjelennek a teljesen egyéni életutakat bejáró hallgatók is, akik lehetőségeket és jelentős erősforrást képviselnek a rendszerben. Éppen ezért a döntéshozóknak figyelembe kell venniük az alternatív lehetőségeket is.

A rész utolsó fejezetében az amerikai felsőoktatás jövőjéről esik szó. Azt a kérdést járja részletesen körül, hogy az egyének életútjában bekövetkezett változások milyen hatással vannak a felsőoktatásra, illetve fordítva. Itt is szó esik az átlagostól eltérő tanulmányi utat bejáró hallgatókról, akik az élethosszig tartó tanulás jegyében, kihívásokkal és nehezítő körülményekkel is megküzdve kerülnek a felsőoktatási rendszerbe, ahol jelentős tényezőt képeznek.

A könyvrész összességében kiváló betekintést ad az Egyesült Államok felsőoktatásának azon szegmensébe, amely nálunk Európában talán kevésbé ismert. Hangsúlyozza az alternatív lehetőségek jelentőségét, az élethosszig tartó tanulás napjainkban egyre fokozódó fontosságát. 
Európaiként is érdemes tájékozódnunk azokról a gyakorlatokról, amelyek a tengerentúlon már jól müködnek, illetve már az is tanulságos, ha csak bepillantást nyerünk abba, hogy ott milyen problémákkal, nehézségekkel küzdenek meg, és milyen megoldási stratégiákkal dolgoznak.

A fejezetek részletes szakirodalmi áttekintéssel rendelkeznek (kettő közülük kifejezetten szakirodalom-elemző és szintetizáló írás), olvasásuk hasznos lehet mindazoknak a szakembereknek, de akár hallgatóknak is, akik rövid, de átfogó ismeretre szeretnének szert tenni a témában. Mivel minden fejezet végén részletes és kifejezetten pontos bibliográfia is található, így az olvasó saját kutatómunkájához is egy jól használható gyüjteményt kap, amely irányadó lehet, például egy szakdolgozat megírásához.

Számomra a legérdekesebb olvasmány a 18. fejezet volt, amely szemléletesen bemutatja, miként vált a community college megkerülhetetlen tényezővé az Egyesült Államok felsőoktatásában, hogyan szolgálja a hátrányos helyzetü, szegényebb csoportok érdekeit, lehetőséget biztosítva számukra is egy felsőfokú végzettség megszerzésére. Magyarországon nem annyira elterjedt az, hogy a felnőttek (pláne nem, hogy az idősebbek, nyugdíjasok) visszaüljenek az iskolapadba, és tét nélkül, csupán kedvtelésből valami nekik tetszőt tanuljanak, növeljék műveltségüket, tudásukat. E téren az amerikai példa követése nyugodtan javasolható lehetne.

A cikk a Creative Commons Attribution 4.0 International License (https://creativecommons.org/licenses/ by/4.0/) feltételei szerint publikált Open Access közlemény, melynek szellemében a cikk bármilyen médiumban szabadon felhasználható, megosztható és újraközölhető, feltéve, hogy az eredeti szerző és a közlés helye, illetve a CC License linkje és az esetlegesen végrehajtott módosítások feltüntetésre kerülnek. (SID_1) 